\title{
Heck and Suzuki cross-couplings of aryl and heteroaryl bromides in water using a new palladium(II)-complex
}

\author{
Kamal M. Dawood, ${ }^{a, *}$ Mohamed S. Fayed, ${ }^{\text {b }}$ and Mohamed M. Elkhalea ${ }^{c}$ \\ ${ }^{a}$ Department of Chemistry, Faculty of Science, Cairo University, Giza 12613, Egypt \\ ${ }^{b}$ Department of Chemical Engineering, Military Technical College, Cairo, Egypt \\ ${ }^{c}$ Excellence Center of Science and Technology, Elsalam-2, Cairo 3066, Egypt \\ E-mail: dr_dawood@yahoo.com
}

\begin{abstract}
A new benzimidazole-based $\mathrm{Pd}$ (II)-complex was prepared and its catalytic activity was evaluated in Heck and Suzuki C-C cross-coupling reactions of aryl and heteroaryl bromides with olefins and arylboronic acids, respectively, under thermal heating using water as a reaction solvent. The factors affecting the optimization of such reactions are studied.
\end{abstract}

Keywords: Palladium, catalysis, C-C cross-coupling, water solvent, aryl halides, olefins

\section{Introduction}

Palladium catalyzed Suzuki-Miyaura cross-coupling reaction represents one of the most widely used processes for the synthesis of biaryls. ${ }^{1-4}$ In addition, palladium-catalyzed Heck reactions of aryl halides with alkenes have also become one of the most powerful tools in organic synthesis for the construction of carbon-carbon bond. ${ }^{5,6}$ From a viewpoint of green sustainable chemistry, organic reactions that can proceed well in aqueous media offer advantages over those occurring in organic solvents. ${ }^{7}$ Recently, our interests are concerned with the use of Pd-catalysts in SuzukiMiyaura and Heck-Mizoroki cross-coupling reactions in aqueous media. ${ }^{8-10}$

Therefore, developing new catalytic systems as catalysts for Suzuki-Miyaura and Heck-Mizoroki cross-coupling reactions for the synthesis of biaryls and disubstituted olefins will be of great importance. To date, various 1-alkylbenzimidazole-based Pd-catalysts have been developed and widely utilized for the Heck and Suzuki cross-coupling reactions. ${ }^{11,12}$ In this work, we synthesized a new benzimidazole-oxime-based $\mathrm{Pd}(\mathrm{II})$-complex and its catalytic activity in the phosphine ligand-free $\mathrm{C}-\mathrm{C}$ cross-coupling reactions was evaluated. The factors affecting the optimization of the reaction conditions were also studied. 


\section{Results and Discussion}

\section{Preparation of the Pd (II)-complex 7}

2-Acetyl-1-methylbenzimidazole-oxime 5 was prepared from 1,2-phenylene diamine as described in Scheme 1 following the reported literature procedures. ${ }^{13}$ Reaction of 2-acetyl-1methylbenzimidazole-oxime 5 with benzyl chloride in the presence of potassium carbonata in ethanol at room temperature gave O-benzyl 2-acetyl-1-methylbenzimidazole-oxime 6 in $79 \%$ yield. The structure of oxime $\mathbf{6}$ was established based on its elemental analysis and spectral data (MS, ${ }^{1} \mathrm{H}$ and ${ }^{13} \mathrm{C}$ NMR). Treatment of the oxime 6 with an equimolar amount of sodium tetrachloropalladate, dissolved in methanol, with stirring at room temperature for $2 \mathrm{~h}$ afforded a yellow precipitate of the Pd(II)-complex 7 in 90\% yield as outlined in Scheme 1. The structure of the $\mathrm{Pd}(\mathrm{II})$-complex 7 was elucidation based on the elemental analyses and spectroscopic data as well as related analogous reported examples. ${ }^{9,14}$

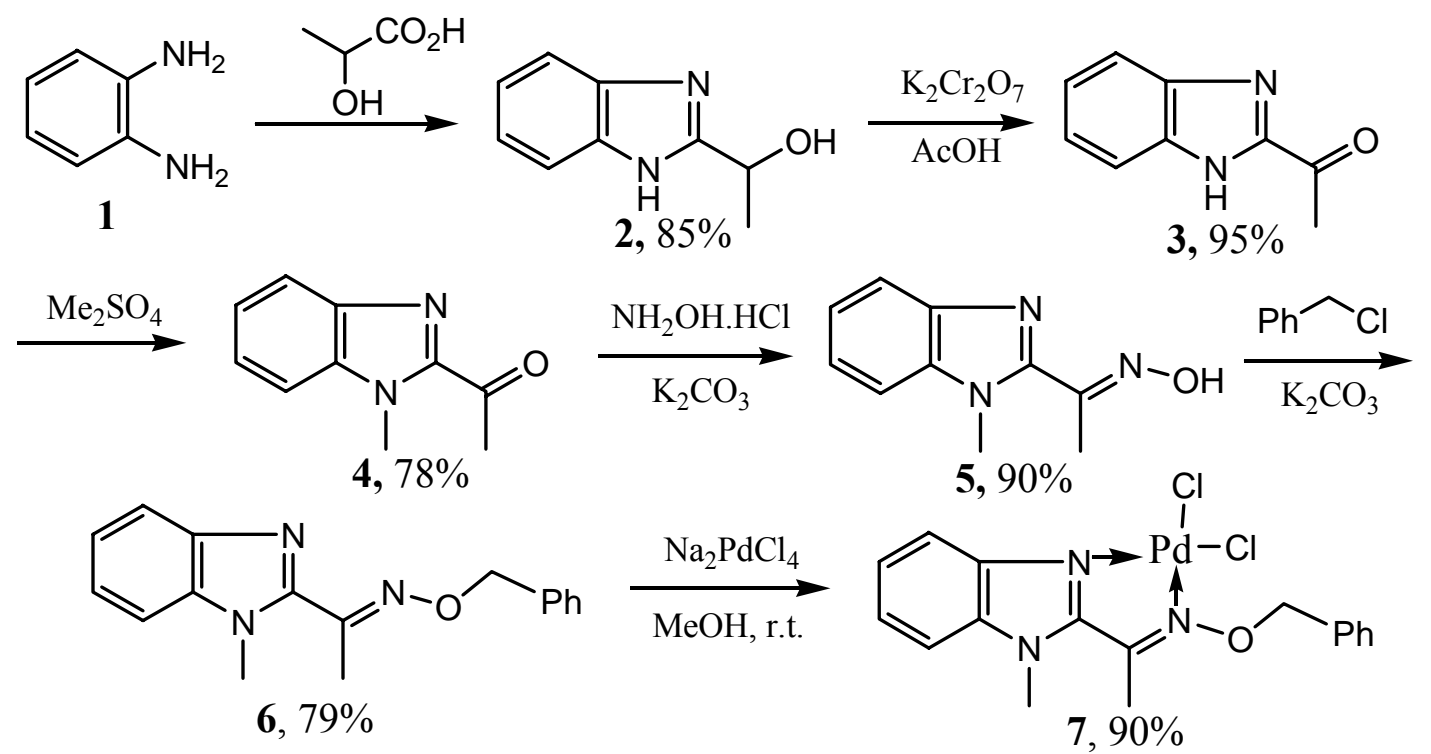

Scheme 1. Preparation of the Pd(II)-complex 7.

The effect of concentration of the $\mathrm{Pd}(\mathrm{II})$ complex 7 on the cross-coupling reaction between 4bromoacetophenone 8 and phenylboronic acid 15a in water at $100{ }^{\circ} \mathrm{C}$ was examined as shown in Table 1. At first, the reaction was conducted in water $(3 \mathrm{~mL})$ using $1 \mathrm{~mol} \%$ of the $\mathrm{Pd}(\mathrm{II})$ complex 7 with $1 \mathrm{mmol}$ 4-bromoacetophenone 8, $1.2 \mathrm{mmol}$ phenylboronic acid, $0.6 \mathrm{mmol}$ tetrabutylammonium bromide (TBAB) and 2 mmoles of potassium hydroxide at boiling temperature. TLC and ${ }^{1} \mathrm{H}$ NMR of crude reaction product showed that 4-bromoacetophenone 8 was completely consumed after one hour of heating and the product 4-acetylbiphenyl 16 was isolated in $94 \%$ yield. Next, the same experiment was repeated using $0.5 \mathrm{~mol} \%$ of the catalyst under the same reaction conditions where complete consumption of the bromide $\mathbf{8}$ was observed 
after one hour at reflux. Again, the same reaction was repeated with $0.25,0.15,0.1$ and 0.05 mol\% of the Pd(II) complex 7 to give full conversion, in each case, after one hour as illustrated in Table 1. When the same reaction was carried out without the Pd(II) complex 7 under the same reaction conditions, the starting material was completely recovered unchanged.

Table 1. Effect of concentration of the Pd(II)-complex 7 on the Suzuki coupling of 4bromoacetophenone $\mathbf{8}$ with phenylboronic acid in water.

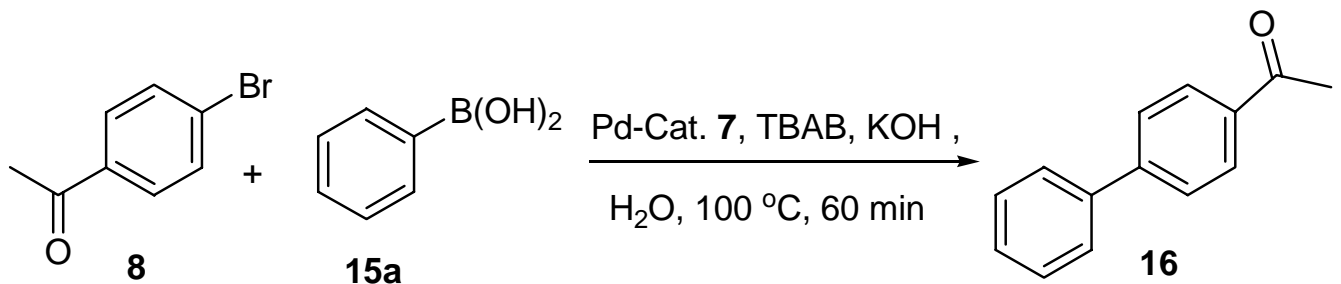

\begin{tabular}{llll}
\hline Entry & Cat. Conc. mol\% & Yield $\%^{a, b}$ & TON \\
\hline 1 & 1 & $100(94)$ & 100 \\
2 & 0.5 & 100 & 200 \\
3 & 0.25 & 100 & 400 \\
4 & 0.15 & $100(93)$ & 666 \\
5 & 0.1 & 100 & 1000 \\
6 & 0.05 & 100 & 2000 \\
7 & 0 & 0 & 0 \\
\hline
\end{tabular}

${ }^{a}$ Conditions: Bromide/ boronic acid/ KOH/ TBAB /water $(3 \mathrm{~mL}): 1 / 1.2 / 2 / 0.6$, at $100{ }^{\circ} \mathrm{C}$ for one hour. ${ }^{b}$ Conversions were based on ${ }^{1} \mathrm{H}$ NMR of crude product and the values between parenthesis refer to the isolated yields.

Similarly, the effect of concentration of the $\mathrm{Pd}(\mathrm{II})$ complex 7 on the cross-coupling reaction between 4-bromoacetophenone $\mathbf{8}\left(\begin{array}{lll}1 & \mathrm{mmol})\end{array}\right.$ and other arylboronic acids (4methoxyphenylboronic acid 15b and 4-chlorophenylboronic acid 15c) $(1.2 \mathrm{mmol})$, in water at $100{ }^{\circ} \mathrm{C}$ was also examined. The reaction was conducted in water $(3 \mathrm{~mL})$ with TBAB and potassium hydroxide at boiling temperature using $1,0.5$ and $0.25 \mathrm{~mol} \%$ of the $\mathrm{Pd}(\mathrm{II})$ complex 7 , respectively. TLC and ${ }^{1} \mathrm{H}$ NMR spectrum of crude reaction product showed in all cases that 4bromoacetophenone 8 was completely consumed after one hour heating.

The efficiencies of different bases and solvents in the coupling reaction between 4bromoacetophenone 8 and phenylboronic acid 15a were also examined. As shown in Table 2, with $0.5 \mathrm{~mol} \%$ of Pd complex 7, the reaction was carried out in different solvents e.g. water, DMF, dioxane and toluene using potassium hydroxide as a base. Full conversion was obtained when water or DMF were used as solvents in the presence of TBAB after one hour at reflux condition (runs 1 and 2, Table 4), where the starting bromide $\mathbf{8}$ was completely consumed (as 
examined by TLC and ${ }^{1} \mathrm{H}-\mathrm{NMR}$ of the crude reaction mixture) and the cross coupled product 4acetylbiphenyl 16 was obtained in 94 and 78\% isolated yields, respectively. When water was replaced with dioxane and with toluene, for the same reaction time, the conversion of the starting material was decreased to 60 and 90\%, respectively (runs 3 and 4, Table 2). Next, the effect of $\mathrm{K}_{2} \mathrm{CO}_{3}$ as a base instead of $\mathrm{KOH}$ was examined using different solvents (water, toluene and dioxane). Again, water proved itself as the efficient solvent in comparison to toluene or dioxane. When cesium carbonate was used as a base in water solvent, it resulted also in full conversion of the bromide $\mathbf{8}$ into 4-acetylbiphenyl $\mathbf{1 6}$ as shown in Table 2.

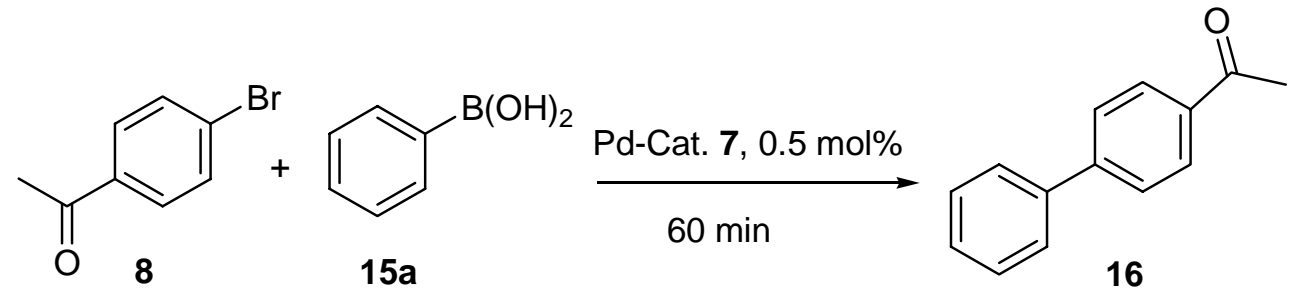

Table 2. Effect of solvent and base on Suzuki coupling 4-bromoacetophenone with phenylboronic acid

\begin{tabular}{llll}
\hline Run & Base & Solvent & Yield\% $^{\mathrm{a}, \mathrm{b}}$ \\
\hline 1 & $\mathrm{KOH}$ & $\mathrm{H}_{2} \mathrm{O}$ & $100(94)$ \\
2 & $\mathrm{KOH}$ & DMF & $100(78)$ \\
3 & $\mathrm{KOH}$ & Dioxane & 60 \\
4 & $\mathrm{KOH}$ & Toluene & 90 \\
5 & $\mathrm{~K}_{2} \mathrm{CO}_{3}$ & $\mathrm{H}_{2} \mathrm{O}$ & $100(83)$ \\
6 & $\mathrm{~K}_{2} \mathrm{CO}_{3}$ & Toluene & 90 \\
7 & $\mathrm{~K}_{2} \mathrm{CO}_{3}$ & Dioxane & 40 \\
8 & $\mathrm{Cs}_{2} \mathrm{CO}_{3}$ & $\mathrm{H}_{2} \mathrm{O}$ & $100(93)$ \\
\hline
\end{tabular}

${ }^{a}$ Conditions: Bromide/ boronic acid/ base/ TBAB/ solvent: 1/1.2/2/0.6/ $3 \mathrm{~mL}$ at refluxing temperature. In case of water as solvent, TBAB was used as phase transfer agent ${ }^{b}$ Conversions were based on ${ }^{1} \mathrm{H}$ NMR of the crude products and the values in parentheses refer to the isolated yields.

Therefore, water as an eco-friendly and a green solvent and $\mathrm{KOH}$ as a cheap and common base are chosen for carrying out all the Suzuki-Miyaura cross-coupling reactions that are performed in this work.

From the above results it is clear that our Pd complex 7 has high thermal stability in water under open air condition. In addition, it has high activity towards $\mathrm{C}-\mathrm{C}$ cross coupling reactions as 
the reaction could be finished after one hour with very low concentration, where $5 \times 10^{-5} \mathrm{mmol}$ of the catalyst are enough to convert $1 \mathrm{mmol}$ of the arylbromide into the corresponding biaryl. This finding may be of interest for industrial mass applications.

\section{Pd-complex 7 in Suzuki coupling of 4-chloroacetophenone with arylboronic acids}

We next turned our attention on the cross-coupling reaction of 4-chloroacetophenone with various arylboronic acids, where chlorides are of particular importance for highly active catalysts. ${ }^{15}$ At first, 4-chloroacetophenone 14 (1 mmol) was coupled with phenylboronic acid $15 \mathbf{a}(1.2 \mathrm{mmol})$ in water $(3 \mathrm{ml})$ in the presence of TBAB $(0.6 \mathrm{mmol})$ using cesium carbonate $(2$ mmol) as base. Under these conditions, $88 \%$ conversion based on ${ }^{1} \mathrm{H}$ NMR spectrum of the crude reaction product were obtained after $6 \mathrm{~h}$ of heating at reflux using $0.5 \mathrm{~mol} \%$ of the palladium complex 7. The use of Pd-complex 7 for similar coupling reaction of 4chloroacetophenone 14 with 4-methoxyphenylboronic acid 15b and with 4-chlorophenylboronic acid $15 \mathrm{c}$ in $0.5 \mathrm{~mol} \%$ resulted in $75 \%$ and $80 \%$ conversions, respectively, after $6 \mathrm{~h}$ heating at reflux.

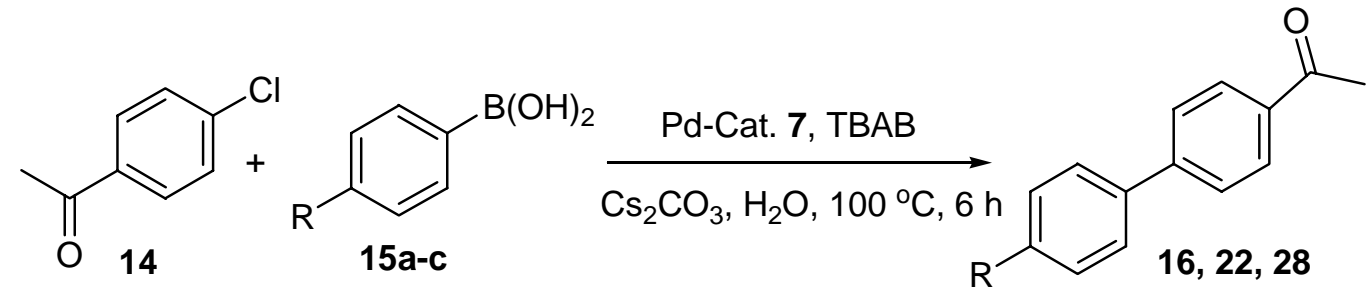

Table 3. Suzuki coupling of 4-chloroacetophenone 14 with arylboronic acids in water

Entry Boronic acids Product

${ }^{a}$ Reaction Conditions: Chloride/ boronic acid/ base/ TBAB/ water $(3 \mathrm{~mL}): 1 / 1.2 / 2 / 0.6$, at $100{ }^{\circ} \mathrm{C}$ for 6 hours. Conversion yields were based on ${ }^{1} \mathrm{H}$ NMR spectrum of the crude products and the value in parentheses refer to the isolated yield. 


\section{Suzuki cross-coupling of aryl (Hetaryl) bromides with arylboronic acids}

We next generalized the utility of Pd-complex 7 in Suzuki-Miyaura cross-coupling reactions under the above optimized conditions. Thus, Suzuki coupling of activated and deactivated aryl(heteroaryl) bromides 8-13 with arylboronic acids 15a-c were carried out at $100{ }^{\circ} \mathrm{C}$ using water as solvent and $\mathrm{KOH}$ as base resulting in the formation of a library of the corresponding cross-coupled products 16-33 in good to excellent isolated yields as shown in Table 4. The reaction components molar ratios were typically; $1 \mathrm{mmol}$ aryl(heteroaryl) bromides 8-13, 1.2 mmol phenylboronic acid 15a-c, $0.6 \mathrm{mmol}$ TBAB, 2 mmoles of $\mathrm{KOH}$ using $0.5 \mathrm{~mol} \%$ of the Pdcomplex 7 in water $(3 \mathrm{~mL})$. Interestingly, the Pd-complex 7 was found to efficiently catalyze the coupling of a wide range of aryl bromides in excellent yields regardless their activating or deactivating substituents and the reactions could be finished mostly within one hour as can be seen in Table 4. Comparing to analogous oxime-based Pd-complexes, ${ }^{8-11}$ our complex proved superior activity where both activated and deactivated aryl bromides as well as heterocyclic bromides could be completely consumed after $1 \mathrm{~h}$ giving the corresponding products in very good to excellent isolated yields as can be seen from Table 4. The identity of the coupling products was confirmed by ${ }^{1} \mathrm{H}$ and ${ }^{13} \mathrm{C}$ NMR, MS spectra and compared with the reported examples in literature whenever possible (see experimental section).

\begin{tabular}{|c|c|c|c|}
\hline $\mathrm{Ar}(\mathrm{Het})-\mathrm{Br}$ & $A r-P(\rho H)$ & 0.5 mol\% Cat. 7, $\mathrm{H}_{2} \mathrm{O}$ & \\
\hline 8-13 & $\begin{array}{c}+\quad \mathrm{Ar}-\mathrm{B}(\mathrm{OH})_{2} \\
15 \mathrm{a}-\mathrm{c}\end{array}$ & TBAB, $\mathrm{KOH}, 100^{\circ} \mathrm{C}$ & $16-33$ \\
\hline
\end{tabular}


Table 4. Suzuki coupling of aryl bromides 8-13 with arylboronic acids 15a-c in water

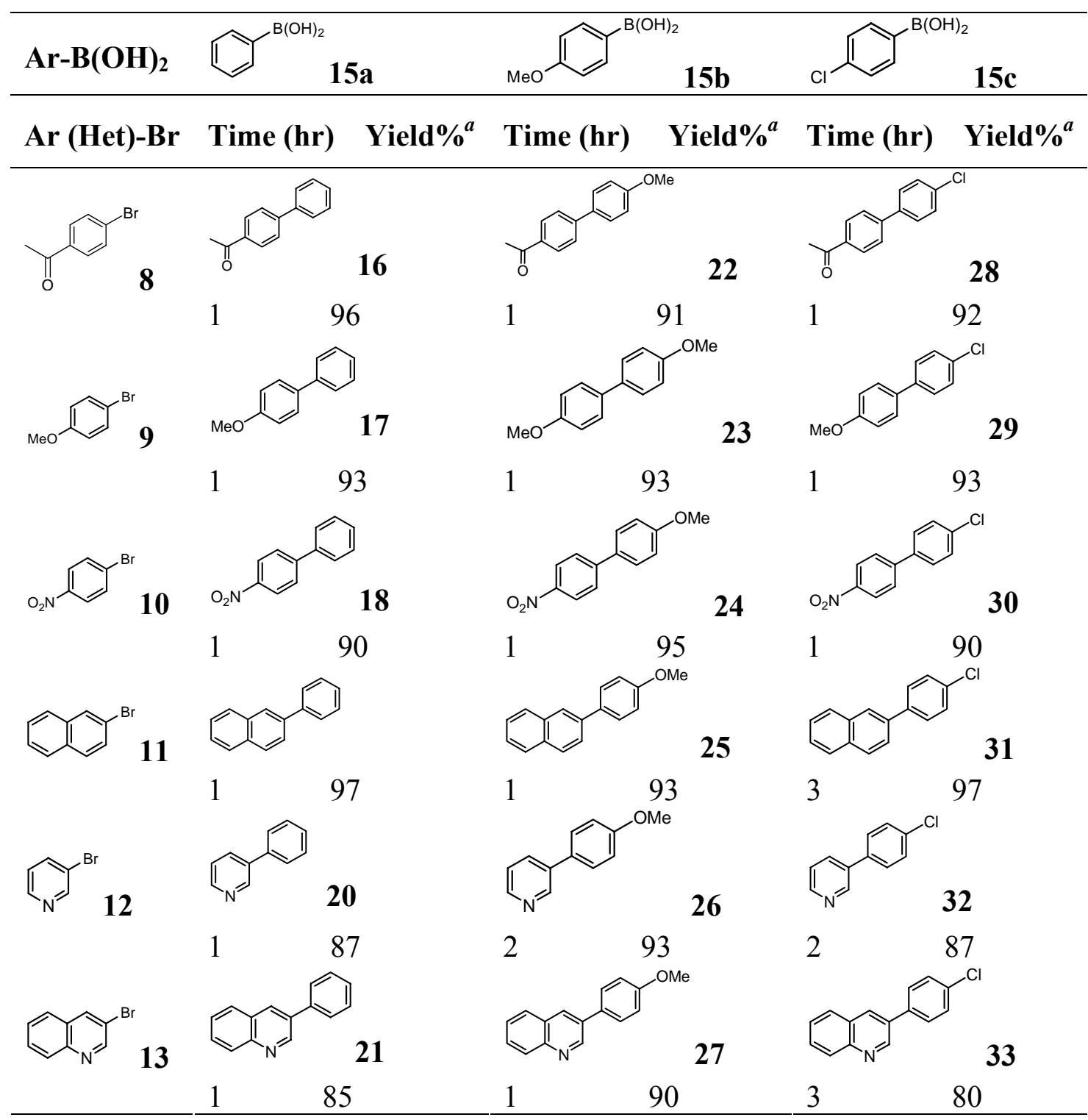

${ }^{a}$ Reaction Conditions: Bromide/ boronic acid/ $\mathrm{KOH} / \mathrm{TBAB} /$ water: 1/1.2/2/0.6/ $3 \mathrm{~mL}$ at $100{ }^{\circ} \mathrm{C}$ temperature. All values refer to the isolated yields.

\section{Mizoroki-Heck cross-coupling of aryl (heteroaryl) bromides with styrene}

The reactivity of the $\mathrm{Pd}$ (II)-complex 7 towards Heck cross-coupling reaction was also investigated. At first, the Heck reaction was performed using $0.5 \mathrm{~mol} \%$ of the $\mathrm{Pd}(\mathrm{II})$-complex 7 with $1 \mathrm{mmol}$ 4-bromoacetophenone $\mathbf{8}, 1.5 \mathrm{mmol}$ styrene, $0.6 \mathrm{mmol}$ TBAB, 2 mmol sodium hydroxide in water $(3 \mathrm{~mL})$ as solvent at $100{ }^{\circ} \mathrm{C}$ as outlined in Table 5 . The starting bromide 8 was completely consumed after $3 \mathrm{~h}$ based on TLC analysis and ${ }^{1} \mathrm{H}$ NMR spectrum of the crude reaction product. 4-Acetylstilbene 35 was isolated in 92\% yield (entry 1, Table 5). The same 
reaction was repeated using $\mathrm{DMF} / \mathrm{NaOH}$ instead of water $/ \mathrm{NaOH}$ at $140{ }^{\circ} \mathrm{C}$ under open air, where complete consumption of the starting bromide was noticed after only one hour (entry 2 , Table 5). Using triethylamine as base and water as solvent resulted in full conversion after $4 \mathrm{~h}$ (entry 3 , Table 5).

The Heck reaction was repeated for a deactivated bromide (4-bromoanisole 9) with styrene in $\mathrm{DMF} / \mathrm{NaOH}$ in the presence of TBAB using $0.5 \mathrm{~mol} \%$ of the Pd complex 7 at $140{ }^{\circ} \mathrm{C}$ for $2 \mathrm{~h}$ (based on TLC) to give 4-methyl-4'-nitrobiphenyl 36 in 87\% yield (entry 4, Table 5). 4Nitrobromobenzene $\mathbf{1 0}$ and 2-bromonaphthalene $\mathbf{1 1}$ were similarly cross-coupled with styrene in DMF or water in the presence of sodium hydroxide or triethylamine and the best results were obtained when DMF/ $\mathrm{NaOH} / \mathrm{TBAB}$ catalytic system was used (entries 6 and 8 , Table 5).

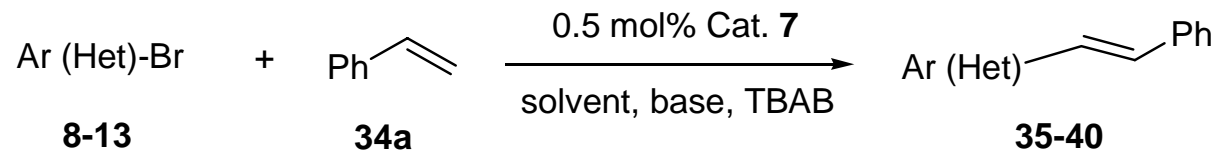

Table 5. Heck cross coupling of aryl (heteroaryl) bromides with styrene

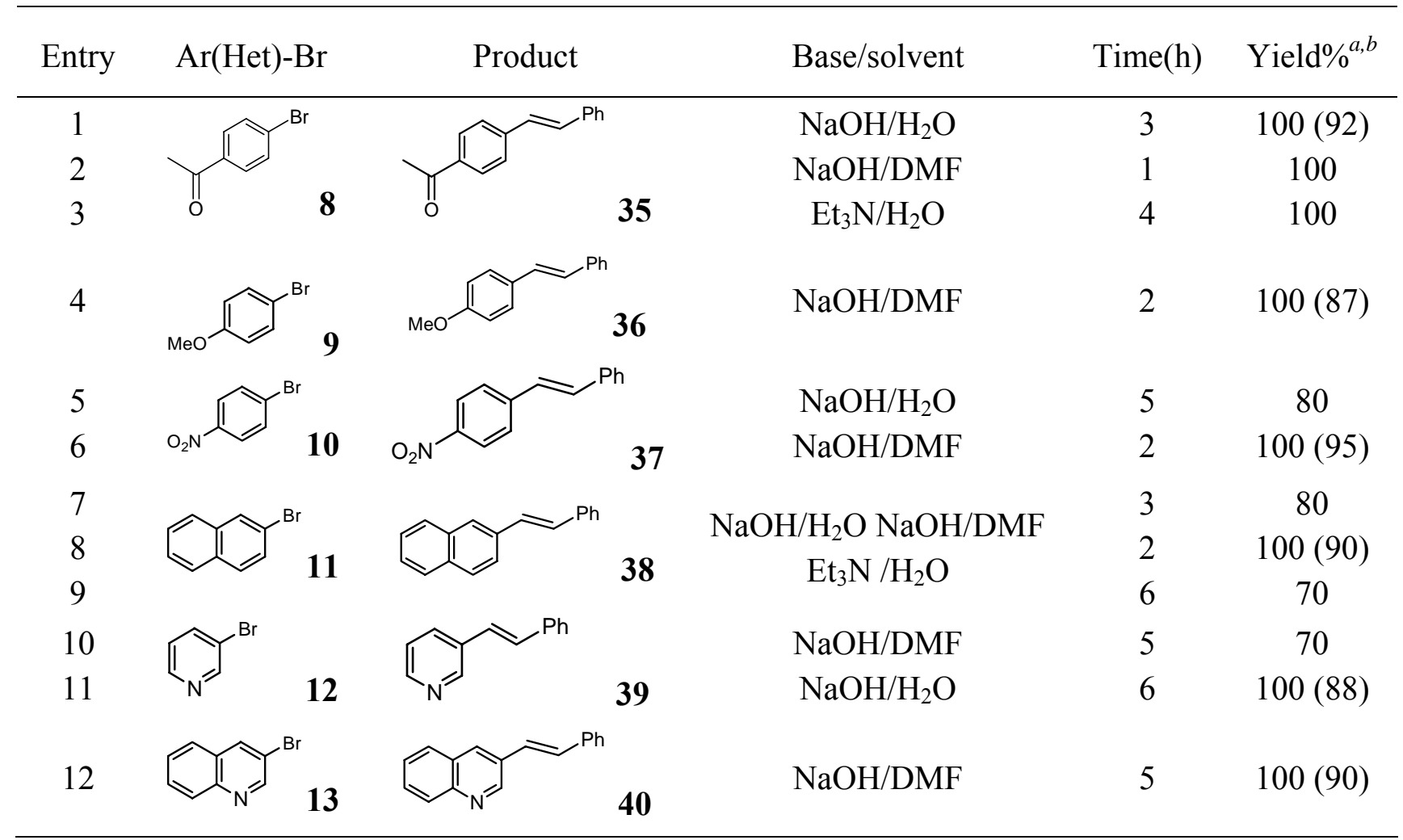

${ }^{a}$ Conditions: Bromide/ styrene/ base/ TBAB/ solvent: $1 / 1.5 / 2 / 0.6 / 3 \mathrm{~mL}$ at $100{ }^{\circ} \mathrm{C}$ for water and at $140{ }^{\circ} \mathrm{C}$ for DMF. ${ }^{b}$ Values in parenthesis refer to the isolated yields

3-Bromopyridine 12 and 3-bromoquinoline 13, as heterocyclic bromides, were similarly cross coupled with styrene to give the corresponding styryl derivatives $\mathbf{3 9}$ and $\mathbf{4 0}$, respectively. 
The cross-coupling of 3-bromopyridine 12 proceeded well in water/ $\mathrm{NaOH}$ system but for 3bromoquinoline $13 \mathrm{DMF} / \mathrm{NaOH}$ system was more suitable (entries 11 and 12, Table 5, respectively). The structures of the Heck coupled products were confirmed by spectral data and were in complete agreement with literature. The ${ }^{1} \mathrm{H}$ NMR spectra of the series prepared revealed, in each case, two characteristic doublets in the aromatic region having coupling constant $J$ value about $16 \mathrm{~Hz}$ which supports the trans-configuration of the resulting disubstituted olefins.

\section{Mizoroki-Heck cross-coupling of aryl (heteroaryl) bromides with t-butyl acrylate}

The Heck cross-coupling reactions of the aryl (heteroaryl) bromides 8-13 with $t$-butylacrylate 34b in $1: 1.5$ molar ratios were also studied. These reactions we conducted mainly in DMF as solvent using $\mathrm{Et}_{3} \mathrm{~N}$ as base in the presence of $0.5 \mathrm{~mol} \%$ of the Pd-complex 7 and the reaction mixture was heated at $140{ }^{\circ} \mathrm{C}$ of under open air. The mixture was heated till the staring bromides were almost consumed after $3 \sim 9 \mathrm{~h}$, based on TLC and/or ${ }^{1} \mathrm{H}$ NMR of the crude reaction products, to give the corresponding t-butyl esters 41-46 in high yields as illustrated in Table 6. The structures of the ester products were confirmed from their spectral data $\left(\mathrm{MS},{ }^{1} \mathrm{H}\right.$ and ${ }^{13} \mathrm{C}$ NMR) and were consistent with the reported data. The ${ }^{1} \mathrm{H}$ NMR spectra of the obtained esters revealed two characteristic doublets having $J$ value about $16 \mathrm{~Hz}$ giving an evidence for the $E$ configuration of the isolated products.

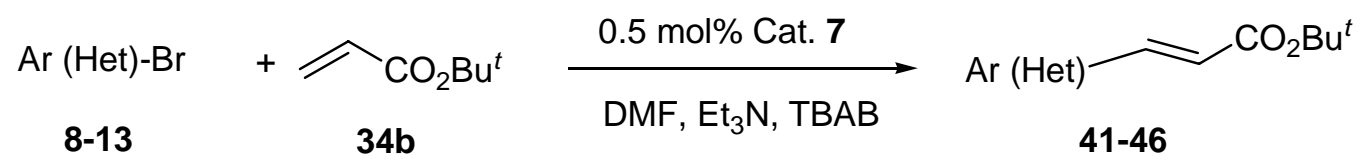


Table 6. Heck cross coupling of aryl (heteroaryl) bromides with $t$-butyl acrylate

Entry

${ }^{a}$ Reaction Conditions: Bromide/ styrene/ $\mathrm{Et}_{3} \mathrm{~N} / \mathrm{TBAB} / \mathrm{DMF}: 1 / 1.5 / 2 / 0.6 / 3 \mathrm{~mL}$ at $140{ }^{\circ} \mathrm{C}$. ${ }^{b}$ Values in parenthesis refer to the isolated yields.

${ }^{c}$ Conversions are based on the ${ }^{1} \mathrm{H}$ NMR spectra of the crude product.

Mizoroki-Heck coupling of 4-chloroacetophenone with $\boldsymbol{t}$-butyl acrylate and styrene

To evaluate the catalytic activity of the Pd complex 7 towards the Heck cross coupling of aryl chlorides with olefins, we carried out the cross-coupling reaction of 4-chloroacetophenone 14 with styrene and with $t$-butyl acrylate. 4-Chloroacetophenone 14 (1 mmol) was coupled with styrene $(1.5 \mathrm{mmol})$ in DMF (3 ml) in the presence of TBAB $(0.6 \mathrm{mmol})$ and $\mathrm{NaOH}(2 \mathrm{mmol})$ as base using $0.5 \mathrm{~mol} \%$ of the palladium complex 7 . Under these conditions, $63 \%$ conversion, based on ${ }^{1} \mathrm{H}$ NMR spectrum of the crude reaction product 35, were obtained after $4 \mathrm{~h}$ of heating at $140{ }^{\circ} \mathrm{C}$. Similar coupling of 4-choloroacetophenone $14(1 \mathrm{mmol})$ with $t$-butyl acrylate $(1.5$ $\mathrm{mmol})$ in DMF $(3 \mathrm{ml})$ in the presence of TBAB $(0.6 \mathrm{mmol})$ and triethylamine $(2 \mathrm{mmol})$ as base using $0.5 \mathrm{~mol} \%$ of Pd-complex 7 was also performed. Unfortunately, under this condition the ester 39 could not be detected at all and the starting bromide 14 was completely recovered unchanged.

In conclusion, the benzimidiazole-oxime-based palladium(II) complex 7 was found to be a very efficient and highly active precatalyst for Suzuki-Miyaura and Heck-Mizoroki crosscoupling reactions of activated and deactivated aryl bromides as well as heteroaryl bromides in water as a green solvent. The reactions were completed mostly within one hour using $0.5 \mathrm{~mol} \%$ of the Pd-complex 7. 


\section{Experimental Section}

General. Melting points were determined in open glass capillaries with a Gallenkamp apparatus. The infrared spectra were recorded in potassium bromide disks on a Pye Unicam SP 3-300 and Shimaduz FTIR 8101 PC infrared spectrophotometer. NMR spectra were recorded with a Varian Mercury VXR-300 NMR spectrometer at $300 \mathrm{MHz}\left({ }^{1} \mathrm{H}\right.$ NMR) and at $75 \mathrm{MHz}\left({ }^{13} \mathrm{C}\right.$ NMR) using $\mathrm{CDCl}_{3}$ as solvent and internal standard $\left(\delta 7.27\right.$ and $77.36 \mathrm{ppm}$, for ${ }^{1} \mathrm{H} \mathrm{NMR}$ and ${ }^{13} \mathrm{C}$ NMR, respectively). Mass spectra (EI) were obtained at $70 \mathrm{eV}$ with a type Shimadzu GCMQP $1000 \mathrm{EX}$ spectrometer. Analytical thin-layer chromatography was performed using pre-coated silica gel 60778 plates (Fluka), and the spots were visualized with UV light at $254 \mathrm{~nm}$. Fluka silica gel 60741 (70-230 mesh) was used for flash column chromatography. 2-( $\alpha-$ Hydroxyethyl)benzimidazole $2,{ }^{16}$ 2-acetylbenzimidazole $3{ }^{13 a}$ 2-acetyl-1-methylbenzimidazole $4,{ }^{13 a}$ 2-acetyl-1-methylbenzimidazole-oxime $5^{13 b}$ were prepared following the reported literature.

O-Benzyl 2-acetyl-1-methylbenzimidazole-oxime $\quad 6$. To a solution of 2-acetyl-1methylbenzimidazole-oxime $5(1.89 \mathrm{~g}, 10 \mathrm{mmol})$ in anhydrous ethanol $(30 \mathrm{ml})$, potassium hydroxide $(0.79 \mathrm{~g}, 14 \mathrm{mmol})$ was added followed by benzyl chloride $(1.77 \mathrm{~g}, 14 \mathrm{mmol})$. The reaction mixture was stirred for a few minutes at room temperature and then heated at $100{ }^{\circ} \mathrm{C}$ for further 30 minutes. The reaction mixture was diluted with water $(30 \mathrm{~mL})$ and then extracted with ethyl acetate $(3 \times 20 \mathrm{~mL})$. The extracts were dried over $\mathrm{MgSO}_{4}$ then evaporated under reduced pressure. The solid product that formed was then recrystallyzed from petroleum ether (60-80) to afford $2.2 \mathrm{~g}$ (79\% yield) of O-benzyl 2-acetyl-1-methylbenzimidazole-oxime $\mathbf{6}$ as white crystals, mp. $55^{\circ} \mathrm{C}$; IR (KBr) $v_{\max } 3058,3020,2915,1454,1359,1001,882,740 \mathrm{~cm}^{-1} ;{ }^{1} \mathrm{H}$ NMR (CDCl3) $\delta 2.54\left(\mathrm{~s}, 3 \mathrm{H}, \mathrm{CH}_{3}\right), 3.90\left(\mathrm{~s}, 3 \mathrm{H}, \mathrm{NCH}_{3}\right), 5.31\left(\mathrm{~s}, 2 \mathrm{H}, \mathrm{OCH}_{2}\right), 7.26-7.31(\mathrm{~m}, 1 \mathrm{H}), 7.32-7.35(\mathrm{~m}$, $4 \mathrm{H}), 7.39-7.43(\mathrm{~m}, 3 \mathrm{H}), 7.80-7.83(\mathrm{~m}, 1 \mathrm{H}) ;{ }^{13} \mathrm{C} \mathrm{NMR}\left(\mathrm{CDCl}_{3}\right) \delta 13.3,32.8,76.7,109.5,120.0$, 122.2, 123.6, 127.9, 128.1, 128.3, 136.9, 137.7, 142.1, 147.9, 150.6; MS m/z (\%) $279\left(6.9, \mathrm{M}^{+}\right)$, 262 (14.1), 157 (9.7), 132 (7.4), 91 (100), 77 (16.6), 65 (11.2), 51 (16.7). Anal. Calcd. For $\mathrm{C}_{17} \mathrm{H}_{17} \mathrm{~N}_{3} \mathrm{O}: \mathrm{C}, 73.11 ; \mathrm{H}, 6.09 ; \mathrm{N}, 15.05$. Found: C, 73.39; H, 5.94; N, 15.02.

Preparation of Pd-complex 7. A solution of sodium tetrachloropalladate $(294 \mathrm{mg}, 1 \mathrm{mmol})$ in methanol $(2 \mathrm{~mL})$ was added dropwise to a stirred solution of O-benzyl 2-acetyl-1methylbenzimidazole-oxime $6(279 \mathrm{mg}, 1 \mathrm{mmol})$ in dioxane / methanol $(4 \mathrm{~mL}, 1: 1, \mathrm{v} / \mathrm{v})$. After stirring for $2 \mathrm{~h}$, the yellow precipitate that formed was filtered off, washed with water then with methanol and dried. The complex 7 was obtained as a yellow powder (411 mg, 90\% yield). Mp. $>300^{\circ} \mathrm{C}$; IR $(\mathrm{KBr}) v_{\max } 3027,2948,1463,1368,1035,946,739 \mathrm{~cm}^{-1} ;{ }^{1} \mathrm{H}$ NMR (DMSO-d 6 ) $\delta$ $2.99\left(\mathrm{~s}, 3 \mathrm{H}, \mathrm{CH}_{3}\right), 3.81\left(\mathrm{~s}, 3 \mathrm{H}, \mathrm{NCH}_{3}\right), 5.39\left(\mathrm{~s}, 2 \mathrm{H}, \mathrm{OCH}_{2}\right), 7.34-7.51(\mathrm{~m}, 7 \mathrm{H}), 7.68-7.72(\mathrm{~m}$, $1 \mathrm{H}), 8.27-8.30(\mathrm{~m}, 1 \mathrm{H}) ;{ }^{13} \mathrm{C} \mathrm{NMR}\left(\mathrm{CDCl}_{3}\right) \delta 16.3,32.8,76.5,111.8,119.5,123.9,124.8,127.9$, 128.1, 128.4, 134.0, 137.2, 138.4, 146.9, 147.8. Anal. Calcd. for $\mathrm{C}_{17} \mathrm{H}_{17} \mathrm{Cl}_{2} \mathrm{~N}_{3} \mathrm{OPd}$ : C, 44.73; $\mathrm{H}$, $3.72 ;$ N, 9.21. Found: C, 44.80; H, 3.91; N, 9.42. 
Effect of concentration of palladium complex 7 on the Suzuki-Miyaura cross-coupling of 4bromoacetophenone with phenylboronic acid in water. In a $10 \mathrm{~mL}$ round-bottom flask, a mixture of 4-bromoacetophenone $8(199 \mathrm{mg}, 1 \mathrm{mmol})$ and phenylboronic acid 15a (146 $\mathrm{mg}$, $1.2 \mathrm{mmol}$ ), TBAB (TBAB) (194 mg, $0.6 \mathrm{mmol})$, palladium(II)-catalyst 7 (4.5 mg, $1 \mathrm{~mol} \%$ ), $\mathrm{KOH}(112 \mathrm{mg}, 2 \mathrm{mmol})$ and water $(3 \mathrm{~mL})$ was heated at $100{ }^{\circ} \mathrm{C}$ for one hour (monitored by TLC). The product was then extracted with EtOAc $(3 \times 20 \mathrm{~mL})$ and the combined organic extracts were dried over anhydrous $\mathrm{Na}_{2} \mathrm{SO}_{4}$ then filtered and the solvent was evaporated under reduced pressure. The residue was then subjected to separation via flash column chromatography with hexane/EtOAc (10:1) as an eluent to give 4-acetylbiphenyl 16 in (96\%) isolated yield. The same experiment was repeated using of palladium complex 7 in different mol\% e.g. $0.5,0.25$ $0.15,0.1$ and $0.05 \mathrm{~mol} \%$ with respect to 4-bromoacetophenone 8 . The molar ratios of the reaction components were in all cases as follows; 4-bromoacetophenone/ phenylboronic acid/ TBAB/ KOH: 1 / 1.2 / 0.6 / 2, in water $3 \mathrm{~mL}$. The yield\% versus concentration of Pd-complex 7 is outlined in Table 1.

Effect of base and solvent on Suzuki-Miyaura cross-coupling of 4-bromoacetophenone with phenylboronic acid. In a $10 \mathrm{~mL}$ round-bottom flask, a mixture of 4-bromoacetophenone 8 (199 mg, $1 \mathrm{mmol}$ ) and phenylboronic acid 15a (146 mg, $1.2 \mathrm{mmol})$, TBAB (TBAB) (194 mg, $0.6 \mathrm{mmol})$, palladium(II)-catalyst $7(2.3 \mathrm{mg}, 0.5 \mathrm{~mol} \%)$, KOH (112 $\mathrm{mg}, 2 \mathrm{mmol})$ and water $(3 \mathrm{~mL})$ was heated at $100{ }^{\circ} \mathrm{C}$ for one hour (monitored by TLC). The same experiment was repeated using different solvents and bases. The molar ratio of the reaction components were in all cases as follows; 4-bromoacetophenone/ phenylboronic acid/ TBAB (in case of water)/ base/ solvent: $1 / 1.2 / 0.6 / 2 / 3 \mathrm{~mL}$. The yield \% versus different solvents and bases is outlined in Table 2 .

Reactivity of Pd complex 7 in Suzuki coupling of 4-chloroacetophenone 14 with arylboronic acids in water. In a $10 \mathrm{~mL}$ round-bottom flask, a mixture of 4-chloroacetophenone 14 (154.5 $\mathrm{mg}, 1 \mathrm{mmol})$ and the appropriate arylboronic acids 15a-c (1.2 mmol), TBAB (TBAB) (194 mg, $0.6 \mathrm{mmol}$ ), palladium (II)-complex 7 (2.3 $\mathrm{mg}, 0.5 \mathrm{~mol} \%$ ), cesium carbonate (650 $\mathrm{mg}$, $2 \mathrm{mmol}$ ) and water $(3 \mathrm{~mL})$ were heated at $100{ }^{\circ} \mathrm{C}$ for the appropriate reaction time (monitored by TLC). The product, in each case, was then extracted with EtOAc and purified with flash column chromatography as shown above to give the biaryl derivatives 16,22 and 28 , respectively, as outlined in Table 3.

Suzuki-Miyaura cross-coupling of aryl(heteroaryl) bromides 8-13 with arylboronic acids $15 a-c$ in water. General procedure

A mixture of the appropriate aryl (heteroaryl) bromides 8-13 (1 mmol), and the appropriate arylboronic acid 15a-c (1.2 mmol), TBAB (194 mg, $0.6 \mathrm{mmol})$, palladium complex 7 (2.3 $\mathrm{mg}$, $0.5 \mathrm{~mol} \%), \mathrm{KOH}(2 \mathrm{mmol})$, and distilled water $(3 \mathrm{~mL})$ was heated with stirring at $100{ }^{\circ} \mathrm{C}$ under open air for the appropriate reaction time listed in Table 4. After the reaction was completed (TLC-monitored), the product was then extracted with EtOAc $(3 \times 20 \mathrm{~mL})$. The combined organic extracts were dried over anhydrous $\mathrm{Na}_{2} \mathrm{SO}_{4}$ then filtered and the solvent was evaporated under 
reduced pressure. The residue was then subjected to separation via flash column chromatography with hexane/EtOAc (10:1) as an eluent to give the corresponding pure cross-coupled products 16-33.

4-Acetylbiphenyl 16. Colorless crystals, mp. 117-119 ${ }^{\circ} \mathrm{C}$ (Ref. ${ }^{17} \mathrm{mp} .118-120{ }^{\circ} \mathrm{C}$ ); ${ }^{1} \mathrm{H}$ NMR $\left(\mathrm{CDCl}_{3}\right) \delta 2.65\left(\mathrm{~s}, 3 \mathrm{H}, \mathrm{CH}_{3} \mathrm{CO}\right), 7.35-7.49(\mathrm{~m}, 3 \mathrm{H}), 7.62-7.65(\mathrm{~m}, 2 \mathrm{H}), 7.70(\mathrm{~d}, 2 \mathrm{H} \mathrm{J}=8.4 \mathrm{~Hz})$, $8.04(\mathrm{~d}, 2 \mathrm{H}, J=8.4 \mathrm{~Hz})$.

4-Methoxybiphenyl 17. Colorless solid; mp. 85-86 ${ }^{\circ} \mathrm{C}$ (Ref. ${ }^{18} \mathrm{mp} .87-88{ }^{\circ} \mathrm{C}$ ); ${ }^{1} \mathrm{H}$ NMR $\left(\mathrm{CDCl}_{3}\right)$ $\delta 3.87\left(\mathrm{~s}, 3 \mathrm{H}, \mathrm{OCH}_{3}\right), 6.99(\mathrm{~d}, 2 \mathrm{H}, J=9 \mathrm{~Hz}), 7.29-7.35(\mathrm{~m}, 1 \mathrm{H}), 7.40-7.46(\mathrm{~m}, 2 \mathrm{H}), 7.53-7.59$ (m, 4H); MS m/z (\%) 184 (M+ 92.5), 169 (77.5), 150 (45.0), 141 (70), 139 (40), 131 (30), 115 (55), 99 (32.5), 91 (52.5), 76 (100), 63 (55.0), 50 (42.5).

4-Nitrobiphenyl 18. Pale yellow powder, mp. $115-116{ }^{\circ} \mathrm{C}$ (Ref. ${ }^{18} \mathrm{mp} .113-114{ }^{\circ} \mathrm{C}$ ); ${ }^{1} \mathrm{H}$ NMR $\left(\mathrm{CDCl}_{3}\right) \delta$ 7.46-7.54 (m, 3H), 7.62-7.66 (m, 2H), $7.75(\mathrm{~d}, 2 \mathrm{H}, J=6.9 \mathrm{~Hz}), 8.31(\mathrm{~d}, 2 \mathrm{H}, J=6.9$ $\mathrm{Hz}) ; \mathrm{MS} \mathrm{m} / \mathrm{z}(\%) 199$ (M+ 35.6$), 169$ (28.9), 153 (19.3), 152 (100), 127 (20.7), 102 (13.3), 76 (49.6), 50 (40).

2-Phenylnaphthalene 19. White crystals, mp. 99-100 ${ }^{\circ} \mathrm{C}$ (Ref. ${ }^{17} \mathrm{mp} .100-101{ }^{\circ} \mathrm{C}$ ); ${ }^{1} \mathrm{H}$ NMR $\left(\mathrm{CDCl}_{3}\right) \delta$ 7.37-7.43 (m, 1H), 7.47-7.56 (m, 4H), 7.73-7.79 (m, 3H), 7.87-7.95 (m, 3H), $8.06(\mathrm{~s}$, 1H); MS m/z (\%) 204 (M+, 73.7), 173 (47.4), 131 (52.6), 109 (47.4), 96 (52.6), 75 (100), 65 (78.9), $51(84.2)$.

3-Phenylpyridine 20. Colorless oil; ${ }^{19}{ }^{1} \mathrm{H}$ NMR $\left(\mathrm{CDCl}_{3}\right) \delta$ 7.43-7.61 (m, 6H), $7.98(\mathrm{~d}, 1 \mathrm{H}, J=$ $7.8 \mathrm{~Hz}), 8.62(\mathrm{~d}, 1 \mathrm{H}, J=3.9 \mathrm{~Hz}), 8.88(\mathrm{~s}, 1 \mathrm{H})$; MS m/z (\%) $155\left(\mathrm{M}^{+}, 100\right), 127$ (20.4), 111 (16.29), 97 (26.73), 85 (25.29), 71 (39.31), 57 (69.58).

3-Phenylquinoline 21. Pale yellow powder, mp. $50{ }^{\circ} \mathrm{C}$ (Ref. $\left.{ }^{20} \mathrm{mp} .52{ }^{\circ} \mathrm{C}\right) ;{ }^{1} \mathrm{H} \mathrm{NMR}\left(\mathrm{CDCl}_{3}\right) \delta$ 7.43-7.61 (m, 4H), 7.71-7.74 (m, 3H), 7.89 (d, 1H, $J=8.1 \mathrm{~Hz}), 8.16(\mathrm{~d}, 1 \mathrm{H}, J=8.7 \mathrm{~Hz}), 8.31(\mathrm{~s}$, 1H), 9.20 (s, 1H); MS m/z (\%) 205 (M+100), 176 (11.4), 151 (5.3), 102 (13), 88 (14.9), 76 (37.2), $61(14.2)$.

4-Acetyl-4'-methoxybiphenyl 22. White crystals; mp. 153-154 ${ }^{\circ} \mathrm{C}$ (Ref. ${ }^{21} \mathrm{mp} .154{ }^{\circ} \mathrm{C}$ ); ${ }^{1} \mathrm{H}$ $\operatorname{NMR}\left(\mathrm{CDCl}_{3}\right) \delta 2.63\left(\mathrm{~s}, 3 \mathrm{H}, \mathrm{COCH}_{3}\right), 3.88\left(\mathrm{~s}, 3 \mathrm{H}, \mathrm{OCH}_{3}\right), 7.01(\mathrm{~d}, 2 \mathrm{H}, J=8.7 \mathrm{~Hz}), 7.58(\mathrm{~d}, 2 \mathrm{H}$, $J=8.7 \mathrm{~Hz}), 7.65(\mathrm{~d}, 2 \mathrm{H}, J=8.4 \mathrm{~Hz}), 8.01(\mathrm{~d}, 2 \mathrm{H}, J=8.4 \mathrm{~Hz}) ; \mathrm{MS} \mathrm{m} / \mathrm{z}(\%) 226\left(\mathrm{M}^{+}, 44\right), 211$ (100), 183 (30.4), 168 (28), 152 (33.6), 139 (65.6), 89 (21.6), 77 (20), 63 (40.8), 55 (27.2).

4,4'-Dimethoxybiphenyl 23. Colorless crystals, mp. 175-176 ${ }^{\circ} \mathrm{C}$ (Ref. ${ }^{18} \mathrm{mp} .174-175{ }^{\circ} \mathrm{C}$ ); ${ }^{1} \mathrm{H}$ NMR $\left(\mathrm{CDCl}_{3}\right) \delta 3.86\left(\mathrm{~s}, 6 \mathrm{H}, \mathrm{OCH}_{3}\right), 6.97(\mathrm{~d}, 4 \mathrm{H}, J=8.7 \mathrm{~Hz}), 7.50(\mathrm{~d}, 4 \mathrm{H}, J=8.7 \mathrm{~Hz}) ; \mathrm{MS} \mathrm{m} / \mathrm{z}$ (\%) $214\left(\mathrm{M}^{+}, 93.4\right), 199$ (100), 171 (36.8), 156 (25), 128 (48.7), 115 (17.1), 102 (28.9), 91 (39.5), 74 (32.9), 63 (47.4), 51 (38.2).

4-Methoxy-4'-nitrobiphenyl 24. Yellow powder, mp. 105-106 ${ }^{\circ} \mathrm{C}$ (Ref. $\left.{ }^{18} \mathrm{mp} .107-108{ }^{\circ} \mathrm{C}\right) ;{ }^{1} \mathrm{H}$ NMR $\left(\mathrm{CDCl}_{3}\right) \delta 3.88\left(\mathrm{~s}, 3 \mathrm{H}, \mathrm{OCH}_{3}\right), 7.02(\mathrm{~d}, 2 \mathrm{H}, J=8.7 \mathrm{~Hz}), 7.58(\mathrm{~d}, 2 \mathrm{H}, J=8.7 \mathrm{~Hz}), 7.70(\mathrm{~d}$, $2 \mathrm{H}, J=8.7 \mathrm{~Hz}), 8.27(\mathrm{~d}, 2 \mathrm{H}, J=8.7 \mathrm{~Hz}),{ }^{13} \mathrm{C} \mathrm{NMR}\left(\mathrm{CDCl}_{3}\right) \delta 55.4,114.6,124.1,127.0,128.5$, 131.1, 147.2, 160.4; MS m/z (\%) 229 (M+1 100), 199 (25.4), 183 (13.9), 168 (23), 139 (49.8), 63 (23.2).

2-(4-Methoxyphenyl)naphthalene 25. White crystals, mp. 133-135 ${ }^{\circ} \mathrm{C}$ (Ref. $\left.{ }^{22} \mathrm{mp} .135-137{ }^{\circ} \mathrm{C}\right)$; ${ }^{1} \mathrm{H} \mathrm{NMR}\left(\mathrm{CDCl}_{3}\right) \delta 3.89\left(\mathrm{~s}, 3 \mathrm{H}, \mathrm{OCH}_{3}\right), 7.04(\mathrm{~d}, 2 \mathrm{H}, J=8.7 \mathrm{~Hz}), 7.46-7.51(\mathrm{~m}, 2 \mathrm{H}), 7.68(\mathrm{~d}, 2 \mathrm{H}$, 
$J=9 \mathrm{~Hz}), 7.72-7.75(\mathrm{~m}, 1 \mathrm{H}), 7.85-7.92(\mathrm{~m}, 3 \mathrm{H}), 8.0(\mathrm{~s}, 1 \mathrm{H})$; MS m/z (\%) $234\left(\mathrm{M}^{+}, 32.5\right), 189$ (25.3), 165 (22.9), 97 (25.3), 69 (39.1), 57 (100).

3-(4-Methoxyphenyl)pyridine 26. Colorless crystals, mp 58-60 ${ }^{\circ} \mathrm{C}$ (Ref. $\left.{ }^{23} \mathrm{mp} .59-60{ }^{\circ} \mathrm{C}\right) ;{ }^{1} \mathrm{H}$ $\operatorname{NMR}\left(\mathrm{CDCl}_{3}\right) \delta 3.87\left(\mathrm{~s}, 3 \mathrm{H}, \mathrm{OCH}_{3}\right), 7.02(\mathrm{~d}, 2 \mathrm{H}, J=8.4 \mathrm{~Hz}), 7.31-7.35(\mathrm{~m}, 1 \mathrm{H}), 7.53(\mathrm{~d}, 2 \mathrm{H}, J$ $=8.4 \mathrm{~Hz}), 7.83(\mathrm{~d}, 1 \mathrm{H}, J=7.8 \mathrm{~Hz}), 8.55(\mathrm{~d}, 1 \mathrm{H}, J=4.2 \mathrm{~Hz}), 8.82(\mathrm{~s}, 1 \mathrm{H}) ;{ }^{13} \mathrm{C} \operatorname{NMR}\left(\mathrm{CDCl}_{3}\right) \delta$ $55.4,114.5,123.4,128.2,130.2,133.8,136.2,147.8,147.9,159.7$; MS m/z (\%) $185\left(\mathrm{M}^{+}, 18.8\right)$, 170 (14.8), 139 (14.8), 115 (17.2), 85 (23.4), 55 (100).

3-(4-Methoxyphenyl)quinoline 27. Yellow crystals, mp. 81-83 ${ }^{\circ} \mathrm{C}$; (Ref. ${ }^{24} \mathrm{mp} .83-85{ }^{\circ} \mathrm{C}$ ); ${ }^{1} \mathrm{H}$ $\operatorname{NMR}\left(\mathrm{CDCl}_{3}\right) \delta 3.88\left(\mathrm{~s}, 3 \mathrm{H}, \mathrm{OCH}_{3}\right), 7.05(\mathrm{~d}, 2 \mathrm{H}, J=8.7 \mathrm{~Hz}), 7.55(\mathrm{~m}, 1 \mathrm{H}), 7.65(\mathrm{~d}, 2 \mathrm{H}, J=8.7$ $\mathrm{Hz}), 7.67-7.73(\mathrm{~m}, 1 \mathrm{H}), 7.85(\mathrm{~d}, 1 \mathrm{H}, J=8.1 \mathrm{~Hz}), 8.13(\mathrm{~d}, 1 \mathrm{H}, J=8.4 \mathrm{~Hz}), 8.23(\mathrm{~d}, 1 \mathrm{H}, J=2.1$ $\mathrm{Hz}), 9.17(\mathrm{~d}, 1 \mathrm{H}, J=2.1 \mathrm{~Hz}) ;{ }^{13} \mathrm{C}$ NMR $\left(\mathrm{CDCl}_{3}\right) \delta 29.7,55.4,114.6,126.9,127.8,128.1,128.4$, 128.9, 129.1, 130.2, 132.3, 133.4, 147, 149.8, 159.8.; MS m/z (\%) $235\left(\mathrm{M}^{+}, 96.4\right), 220$ (63.3), 192 (43.4), 165 (26.5), 139 (13.3), 118 (10.7), 86 (100), 58 (43.9).

4-Acetyl-4'-chlorobiphenyl 28. White crystals, mp. 101-102 ${ }^{\circ} \mathrm{C}$ (Ref. ${ }^{21} \mathrm{mp} .101-103{ }^{\circ} \mathrm{C}$ ); ${ }^{1} \mathrm{H}$ $\operatorname{NMR}\left(\mathrm{CDCl}_{3}\right) \delta 2.64\left(\mathrm{~s}, 3 \mathrm{H}, \mathrm{COCH}_{3}\right), 7.44(\mathrm{~d}, 2 \mathrm{H}, J=8.4 \mathrm{~Hz}), 7.55(\mathrm{~d}, 2 \mathrm{H}, J=8.4 \mathrm{~Hz}), 7.65(\mathrm{~d}$, $2 \mathrm{H}, J=8.4 \mathrm{~Hz}), 8.04(\mathrm{~d}, 2 \mathrm{H}, J=8.4 \mathrm{~Hz}) ;{ }^{13} \mathrm{C} \mathrm{NMR}\left(\mathrm{CDCl}_{3}\right) \delta 26.6,127,128.4,128.9,129.1$, 134.4, 136.1, 138.3, 144.4, 197.5; MS m/z (\%) 230 (M+, 52), 217 (68), 204 (100), 150 (72), 108 (88), 88 (68), 74 (100), 67 (40).

4-Chloro-4'-methoxybiphenyl 29. White crystals, mp. 112-114 ${ }^{\circ} \mathrm{C}$ (Ref. $\left.{ }^{25} \mathrm{mp} .110-112{ }^{\circ} \mathrm{C}\right) ;{ }^{1} \mathrm{H}$ NMR $\left(\mathrm{CDCl}_{3}\right) \delta 3.86\left(\mathrm{~s}, 3 \mathrm{H}, \mathrm{OCH}_{3}\right), 6.98(\mathrm{~d}, 2 \mathrm{H}, J=8.7 \mathrm{~Hz}), 7.38(\mathrm{~d}, 2 \mathrm{H}, J=8.4 \mathrm{~Hz}), 7.47-$ $7.51(\mathrm{~m}, 4 \mathrm{H}) ;{ }^{13} \mathrm{C} \mathrm{NMR}\left(\mathrm{CDCl}_{3}\right) \delta 55.3,114.3,125.9,127.9,128,128.8,132.5,139.2,159.3$; MS m/z (\%) $220\left(\mathrm{M}^{+}+2,37.7\right), 218\left(\mathrm{M}^{+}, 88.7\right), 203$ (66), 175 (62.3), 152 (47.2), 139 (56.6), 111 (24.5), 101 (30.2), 87 (49.1), 75 (67.9), 63 (79.2), 57 (100).

4-Chloro-4'-nitrobiphenyl 30. Pale yellow powder, mp. 138-139 ${ }^{\circ} \mathrm{C}$ (Ref. mp. 112-113 ${ }^{\circ} \mathrm{C}^{26 \mathrm{a}}$ and. $\left.144{ }^{\circ} \mathrm{C}^{26 \mathrm{~b}}\right) ;{ }^{1} \mathrm{H}$ NMR $\left(\mathrm{CDCl}_{3}\right) \delta 7.49(\mathrm{~d}, 2 \mathrm{H}, J=8.7 \mathrm{~Hz}), 7.57(\mathrm{~d}, 2 \mathrm{H}, J=8.7 \mathrm{~Hz}), 7.70(\mathrm{~d}$, $2 \mathrm{H}, J=8.7 \mathrm{~Hz}), 8.30(\mathrm{~d}, 2 \mathrm{H}, J=9 \mathrm{~Hz}) ;{ }^{13} \mathrm{C} \mathrm{NMR}\left(\mathrm{CDCl}_{3}\right) \delta 124.5,125.9,127.6,128.6,129.3$, 135.2, 137.2, 146.3; MS m/z (\%) $235\left(\mathrm{M}^{+}+2,10.4\right), 233\left(\mathrm{M}^{+}, 17.2\right), 203$ (31.3), 175 (26.9), 152 (100), 126 (11.2), 113 (11.2), 101 (21.6), 75 (32.8), 63 (26.9), 57 (43.3).

2-(4-Chlorophenyl)naphthalene 31. White crystals, mp. 131-132 ${ }^{\circ} \mathrm{C}$ (Ref. ${ }^{27} \mathrm{mp} .133-134{ }^{\circ} \mathrm{C}$ ); ${ }^{1} \mathrm{H} \mathrm{NMR}\left(\mathrm{CDCl}_{3}\right) \delta 7.48(\mathrm{~d}, 2 \mathrm{H}, J=8.4 \mathrm{~Hz}), 7.52-7.57(\mathrm{~m}, 2 \mathrm{H}), 7.67(\mathrm{~d}, 2 \mathrm{H}, J=8.4 \mathrm{~Hz}), 7.71$ (dd, $1 \mathrm{H}, J=8.7,1.8 \mathrm{~Hz}), 7.88-7.95(\mathrm{~m}, 3 \mathrm{H}), 8.02(\mathrm{~s}, 1 \mathrm{H}) ;{ }^{13} \mathrm{C} \mathrm{NMR}\left(\mathrm{CDCl}_{3}\right) \delta 125.2,125.7$, $125.9,126.1,126.4,127.6,128.2,128.6,128.9,132.7,133.5,133.6,137.3,139.5 ; \mathrm{MS} \mathrm{m} / \mathrm{z}(\%)$ $240\left(\mathrm{M}^{+}+2,38.5\right), 238\left(\mathrm{M}^{+}, 82\right), 215$ (20.5), 202 (64.1), 152 (92.3), 126 (23.1), 111 (17.9), 101 (76.9), 81 (84.6), 75 (64.1), 57 (100).

3-(4-Chlorophenyl)pyridine 32. Colorless oil; ${ }^{28}{ }^{1} \mathrm{H}$ NMR $\left(\mathrm{CDCl}_{3}\right) \delta$ 7.44-7.55 (m, 5H), $7.94(\mathrm{~d}$, $1 \mathrm{H}, J=8.1 \mathrm{~Hz}), 8.63(\mathrm{~d}, 1 \mathrm{H}, J=4.8 \mathrm{~Hz}), 8.85(\mathrm{~s}, 1 \mathrm{H}) ;{ }^{13} \mathrm{C} \mathrm{NMR}\left(\mathrm{CDCl}_{3}\right) \delta 124.1,126,126.1$, 128.4, 129.4, 134.8, 135.4, 146.8, 147.4; MS m/z (\%) $191\left(\mathrm{M}^{+}+2,27.6\right), 190\left(\mathrm{M}^{+}+1,12.6\right), 189$ $\left(\mathrm{M}^{+}, 79.5\right), 167$ (11.4), 154 (38.8), 149 (63.7), 127 (39.7), 98 (25.7), 85 (42.3), 71 (66), 57 (100). 3-(4-Chlorophenyl)quinoline 33. White crystals, mp. $135-136{ }^{\circ} \mathrm{C}$ (Ref. $\left.{ }^{29} \mathrm{mp} .133-134{ }^{\circ} \mathrm{C}\right)$; ${ }^{1} \mathrm{H}$ $\operatorname{NMR}\left(\mathrm{CDCl}_{3}\right) \delta 7.51(\mathrm{~d}, 2 \mathrm{H}, J=8.7 \mathrm{~Hz}), 7.58-7.66(\mathrm{~m}, 3 \mathrm{H}), 7.73-7.78(\mathrm{~m}, 1 \mathrm{H}), 7.90(\mathrm{~d}, 1 \mathrm{H}, J=$ 
$8.4 \mathrm{~Hz}), 8.19(\mathrm{~d}, 1 \mathrm{H}, J=8.4 \mathrm{~Hz}), 8.31(\mathrm{~d}, 1 \mathrm{H}, J=2.1 \mathrm{~Hz}), 9.15(\mathrm{~d}, 1 \mathrm{H}, J=2.4 \mathrm{~Hz}) ;{ }^{13} \mathrm{C} \mathrm{NMR}$ $\left(\mathrm{CDCl}_{3}\right) \delta 125.9,127.4,127.9,128.6,128.8,129.4,129.9,132.7,133.6,134.5,136.1,146.8$, 149.0; MS m/z (\%) $241\left(\mathrm{M}^{+}+2,37.1\right), 240\left(\mathrm{M}^{+}+1,26.6\right), 239\left(\mathrm{M}^{+}, 100\right), 204$ (37.3), 176 (25.3), 102 (12.2), 88 (45.7), 75 (29.6), 63 (13.8), 50 (23).

\section{Mizoroki-Heck cross-coupling of aryl (heteroaryl) bromides 8-13 with olefins 34a,b. General procedure}

In a $10-\mathrm{mL}$ round bottomed flask, a mixture of the appropriate aryl (heteroaryl) bromide 8-13 $(1 \mathrm{mmol})$ and the appropriate olefin 34a,b (1.5 mmol), TBAB (194 mg, $0.6 \mathrm{mmol})$, Pd-complex $7(2.3 \mathrm{mg}, 0.5 \mathrm{~mol} \%$ ), and the appropriate base (potassium hydroxide, sodium hydroxide or triethylamine) $(3 \mathrm{mmol})$ in water or DMF $(3 \mathrm{~mL})$ were heated at $100{ }^{\circ} \mathrm{C}$ for water and $140{ }^{\circ} \mathrm{C}$ for DMF with stirring under open air for the appropriate reaction time as listed in Tables 5 and 6. After the reaction was almost complete (monitored by TLC), the reaction mixture was left to cool to room temperature, then extracted three times with EtOAc $(3 \times 20 \mathrm{~mL})$. The organic fractions were combined altogether, dried over $\mathrm{MgSO}_{4}$, and the solvent was then removed under vacuum. The residue was subjected to purification via flash column chromatography with Hexane-EtOAc (10:1) as eluent to give the corresponding pure products 35-46.

Mizoroki-Heck cross-coupling of 4-chloroacetophenone 14 with olefins 34a,b. In a $10-\mathrm{mL}$ round bottomed flask, a mixture of 4-chloroacetophenone $14(1 \mathrm{mmol})$ and styrene $34 \mathrm{a}$ or $t$-butyl acrylate 34b (1.5 mmol), TBAB (194 mg, $0.6 \mathrm{mmol})$, Pd-complex 7 (2.3 mg, $0.5 \mathrm{~mol} \%$ ), and the appropriate base (sodium hydroxide or triethylamine) $(3 \mathrm{mmol})$ in DMF $(3 \mathrm{~mL})$ were heated at $140{ }^{\circ} \mathrm{C}$ with stirring under open air for the appropriate reaction time as listed in Table 7. After the reaction was almost complete (monitored by TLC), the reaction mixture was left to cool to room temperature, then extracted three times with EtOAc $(3 \times 20 \mathrm{~mL})$. The organic fractions were combined altogether, dried over $\mathrm{MgSO}_{4}$, and the solvent was then removed under vacuum. The residue was subjected to purification via flash column chromatography with Hexane-EtOAc $(10: 1)$.

trans-4-Acetylstilbene 35. Colorless crystals, mp. 138-140 ${ }^{\circ} \mathrm{C}$ (Ref. $\left.{ }^{30} \mathrm{mp} .141-142{ }^{\circ} \mathrm{C}\right)$; ${ }^{1} \mathrm{H}$ $\operatorname{NMR}\left(\mathrm{CDCl}_{3}\right) \delta 2.62\left(\mathrm{~s}, 3 \mathrm{H}, \mathrm{CH}_{3} \mathrm{CO}\right), 7.14(\mathrm{~d}, 1 \mathrm{H}, J=16.2 \mathrm{~Hz}), 7.24(\mathrm{~d}, 1 \mathrm{H}, J=16.2 \mathrm{~Hz}), 7.31-$ $7.42(\mathrm{~m}, 3 \mathrm{H}), 7.54-7.57(\mathrm{~m}, 2 \mathrm{H}), 7.60(\mathrm{~d}, 2 \mathrm{H}, J=8.4 \mathrm{~Hz}), 7.97(\mathrm{~d}, 2 \mathrm{H}, J=8.4 \mathrm{~Hz}) ;{ }^{13} \mathrm{C}$ NMR $\left(\mathrm{CDCl}_{3}\right) \delta 26.6,126.5,126.8,127.5,128.3,128.8,128.9,131.5,136.7,142.0,197.6 ; \mathrm{MS} \mathrm{m} / \mathrm{z}$ (\%) $222\left(\mathrm{M}^{+}, 53.4\right), 207$ (100), 178 (53), 152 (11), 104 (11.6), 89 (31), 76 (19.7), 63 (12.5), 51 (17.4).

trans-4-Methoxystilbene 36. White crystals, mp. 134-135 ${ }^{\circ} \mathrm{C}\left(\operatorname{Ref}^{21} \mathrm{mp} .136{ }^{\circ} \mathrm{C}\right)$; ${ }^{1} \mathrm{H}$ NMR $\left(\mathrm{CDCl}_{3}\right) \delta 3.84\left(\mathrm{~s}, 3 \mathrm{H}, \mathrm{OCH}_{3}\right), 6.91(\mathrm{~d}, 2 \mathrm{H}, J=8.4 \mathrm{~Hz}), 6.98(\mathrm{~d}, 1 \mathrm{H}, J=16.5 \mathrm{~Hz}), 7.08(\mathrm{~d}, 1 \mathrm{H}, J$ $=16.5 \mathrm{~Hz}), 7.22-7.38(\mathrm{~m}, 3 \mathrm{H}), 7.45-7.52(\mathrm{~m}, 4 \mathrm{H}) ; \mathrm{MS} \mathrm{m} / \mathrm{z}(\%) 210\left(\mathrm{M}^{+}, 100\right), 195$ (23.3), 167 (34.1), 152 (26.3), 105 (10.1), 89 (20), 76 (18.9), 63 (24.4).

trans-4-Nitrostilbene 37. Yellow crystals, mp. $153-154{ }^{\circ} \mathrm{C}\left(\operatorname{Ref}^{21} \mathrm{mp} .154{ }^{\circ} \mathrm{C}\right) ;{ }^{1} \mathrm{H}$ NMR $\left(\mathrm{CDCl}_{3}\right) \delta 7.15(\mathrm{~d}, 1 \mathrm{H}, J=16.2 \mathrm{~Hz}), 7.29(\mathrm{~d}, 1 \mathrm{H}, J=16.5 \mathrm{~Hz}), 7.34-7.44(\mathrm{~m}, 3 \mathrm{H}), 7.55-7.58(\mathrm{~m}$, 2H), $7.64(\mathrm{~d}, 2 \mathrm{H}, J=8.7 \mathrm{~Hz}), 8.23$ (d, 2H, $J=8.7 \mathrm{~Hz})$; MS m/z (\%) $225\left(\mathrm{M}^{+}, 28.6\right), 178$ (100), 
152 (28), 126 (15.4), 102 (21.1), 87 (22.3), 76 (25.7), 63 (49.1), 51 (78.9).

trans-2-Styrylnaphthalene 38. White crystals, mp. 142-144 ${ }^{\circ} \mathrm{C}$ (Ref. ${ }^{31} \mathrm{mp} .143-145{ }^{\circ} \mathrm{C}$ ); ${ }^{1} \mathrm{H}$ $\operatorname{NMR}\left(\mathrm{CDCl}_{3}\right) \delta 7.28(\mathrm{~d}, 2 \mathrm{H}, J=3.3 \mathrm{~Hz}), 7.33(\mathrm{~d}, 1 \mathrm{H}, J=5.4 \mathrm{~Hz}), 7.38-7.42(\mathrm{~m}, 2 \mathrm{H}), 7.43-7.50$ (m, 2H), 7.59 (d, $2 \mathrm{H}, J=7.2 \mathrm{~Hz}), 7.76(\mathrm{~d}, 1 \mathrm{H}, J=9.3 \mathrm{~Hz}), 7.84(\mathrm{~d}, 2 \mathrm{H}, J=3.0 \mathrm{~Hz}), 7.87$ (d, 2H, $J=6.6 \mathrm{~Hz}$ ); MS m/z (\%) 230 (M+100), 215 (21.3), 114 (36.4), 74 (16.2), 63 (13.4), 51 (33.6).

trans-3-Styrylpyridine 39. Yellow crystals, mp. 79-80 ${ }^{\circ} \mathrm{C}$ (Ref. ${ }^{32} \mathrm{mp} .80-81{ }^{\circ} \mathrm{C}$ ); ${ }^{1} \mathrm{H}$ NMR $\left(\mathrm{CDCl}_{3}\right) \delta 7.08(\mathrm{~d}, 1 \mathrm{H}, J=16.2 \mathrm{~Hz}), 7.21(\mathrm{~d}, 1 \mathrm{H}, J=16.2 \mathrm{~Hz}), 7.27-7.42(\mathrm{~m}, 4 \mathrm{H}), 7.52-7.56(\mathrm{~m}$, $2 \mathrm{H}), 7.91(\mathrm{~d}, 1 \mathrm{H}, J=7.8 \mathrm{~Hz}), 8.5(\mathrm{~s}, 1 \mathrm{H}), 8.76(\mathrm{~s}, 1 \mathrm{H}) ;{ }^{13} \mathrm{C} \mathrm{NMR}\left(\mathrm{CDCl}_{3}\right) \delta 123.9,124.3,125.9$, 126, 126.7, 128.4, 128.8, 131.6, 133.6, 136.4, 147.2; MS m/z (\%) $181\left(\mathrm{M}^{+}, 37.7\right), 152$ (16.4), 121 (19.7), 115 (19.7), 105 (75.4), 83 (21.3), 77 (70.5), 65 (24.6), 51 (100).

trans-3-Styrylquinoline 40. Pale yellow crystals, mp. 96-97 ${ }^{\circ} \mathrm{C}$ (Ref. ${ }^{32} \mathrm{mp} .97-98{ }^{\circ} \mathrm{C}$ ); ${ }^{1} \mathrm{H}$ NMR $\left(\mathrm{CDCl}_{3}\right) \delta 7.24(\mathrm{~d}, 1 \mathrm{H}, J=16.2 \mathrm{~Hz}), 7.30-7.44(\mathrm{~m}, 4 \mathrm{H}), 7.54-7.60(\mathrm{~m}, 3 \mathrm{H}), 7.67-7.73(\mathrm{~m}, 1 \mathrm{H})$, $7.84(\mathrm{~d}, 1 \mathrm{H}, J=7.5 \mathrm{~Hz}), 8.13(\mathrm{~d}, 1 \mathrm{H}, J=8.4 \mathrm{~Hz}), 8.2(\mathrm{~d}, 1 \mathrm{H}, J=2.1 \mathrm{~Hz}), 9.14(\mathrm{~d}, 1 \mathrm{H}, J=2.1$ $\mathrm{Hz}) ;{ }^{13} \mathrm{C} \mathrm{NMR}\left(\mathrm{CDCl}_{3}\right) \delta 125,125.9,126.7,127.2,127.8,128.2,128.3,128.8,129.4,130.4$, 131.2, 132.6, 136.6, 146.9, 149; MS m/z (\%) $231\left(\mathrm{M}^{+}, 65.2\right), 230$ (100), 202 (33.7), 149 (19.6), 127 (12.0), 115 (19.6), 101 (26.1), 84 (19.6), 76 (47.8), 63 (16.3), 55 (47.8).

trans-tert-Butyl 3-(4-acetylphenyl)prop-2-enoate 41. Pale yellow crystals, mp. $97-98{ }^{\circ} \mathrm{C}$ (Ref. $\left.{ }^{19} \mathrm{mp} .99-100{ }^{\circ} \mathrm{C}\right) ;{ }^{1} \mathrm{H}$ NMR $\left(\mathrm{CDCl}_{3}\right) \delta 1.55\left(\mathrm{~s}, 9 \mathrm{H}, \mathrm{C}\left(\mathrm{CH}_{3}\right)_{4}\right), 2.61\left(\mathrm{~s}, 3 \mathrm{H}, \mathrm{CH}_{3} \mathrm{CO}\right), 6.46$ $(\mathrm{d}, 1 \mathrm{H}, J=16.2 \mathrm{~Hz}), 7.58-7.63(\mathrm{~m}, 3 \mathrm{H}), 7.96(\mathrm{~d}, 2 \mathrm{H}, J=7.8 \mathrm{~Hz}) ; \mathrm{MS} \mathrm{m} / \mathrm{z}(\%) 246\left(\mathrm{M}^{+} 6.5\right) 190$ (20.1), 175 (59), 131 (9.4), 102 (25.2), 91 (13.7), 79 (11.5), 57 (100).

trans-tert-Butyl 3-(4-methoxphenyl)prop-2-enoate 42. Pale yellow oil; ${ }^{19}{ }^{1} \mathrm{H}$ NMR $\left(\mathrm{CDCl}_{3}\right)$ $\delta 1.54\left(\mathrm{~s}, 9 \mathrm{H}, \mathrm{C}\left(\mathrm{CH}_{3}\right)_{4}\right), 3.84(\mathrm{~s}, 3 \mathrm{H}, \mathrm{OCH} 3), 6.43(\mathrm{~d}, 1 \mathrm{H}, J=15.9 \mathrm{~Hz}), 6.89(\mathrm{~d}, 2 \mathrm{H}, J=8.7 \mathrm{~Hz})$, $7.46(\mathrm{~d}, 2 \mathrm{H}, J=8.7 \mathrm{~Hz}), 7.55(\mathrm{~d}, 1 \mathrm{H}, J=15.9 \mathrm{~Hz}) ;{ }^{13} \mathrm{C} \mathrm{NMR}\left(\mathrm{CDCl}_{3}\right) \delta 28.2,55.3,80.2,114.2$, 117.7, 127.4, 129.5, 143.2, 161.1, 166.6; MS m/z (\%) 234 (M+12.6), 224 (16.73), 178 (69.84), 161 (29.86), 150 (8.83), 133 (18.15), 119 (9.24), 103 (10.82), 89 (14.67), 77 (23.2), 57 (100).

trans-tert-Butyl 3-(4-nitrophenyl)prop-2-enoate 43. White crystals, mp. 143-144 ${ }^{\circ} \mathrm{C}$ (Ref. ${ }^{19}$ mp. 144-146 $\left.{ }^{\circ} \mathrm{C}\right) ;{ }^{1} \mathrm{H}$ NMR $\left(\mathrm{CDCl}_{3}\right) \delta 1.55\left(\mathrm{~s}, 9 \mathrm{H}, \mathrm{C}\left(\mathrm{CH}_{3}\right)_{4}\right), 6.49(\mathrm{~d}, 1 \mathrm{H}, J=16.2 \mathrm{~Hz}), 7.61(\mathrm{~d}$, $1 \mathrm{H}, J=16.2 \mathrm{~Hz}), 7.66(\mathrm{~d}, 2 \mathrm{H}, J=8.7 \mathrm{~Hz}), 8.24(\mathrm{~d}, 2 \mathrm{H}, J=8.7 \mathrm{~Hz}) ;{ }^{13} \mathrm{C} \mathrm{NMR}\left(\mathrm{CDCl}_{3}\right) \delta 28.1$, 81.3, 124.1, 124.6, 128.5, 140.6, 140.9, 148.4, 165.2; MS m/z (\%) 249 (M+1 7.4), 194 (28.4), 176 (39.5), 147 (11.1), 130 (15.8), 102 (23.7), 90 (19.5), 75 (13.2), 57 (100).

trans-tert-Butyl 3-(2-naphthyl)prop-2-enoate 44. White crystals, mp. $73-75{ }^{\circ} \mathrm{C}$ (Ref. ${ }^{29} \mathrm{mp} .74-$ $\left.75^{\circ} \mathrm{C}\right) ;{ }^{1} \mathrm{H} \mathrm{NMR}\left(\mathrm{CDCl}_{3}\right) \delta 1.57\left(\mathrm{~s}, 9 \mathrm{H}, \mathrm{C}\left(\mathrm{CH}_{3}\right)_{4}\right), 6.50(\mathrm{~d}, 1 \mathrm{H}, J=15.9 \mathrm{~Hz}), 7.49-7.52(\mathrm{~m}, 2 \mathrm{H})$, $7.66(\mathrm{~d}, 1 \mathrm{H}, J=8.7 \mathrm{~Hz}), 7.76(\mathrm{~d}, 1 \mathrm{H}, J=15.9 \mathrm{~Hz}), 7.81-7.87(\mathrm{~m}, 3 \mathrm{H}), 7.92(\mathrm{~s}, 1 \mathrm{H}) ; \mathrm{MS} \mathrm{m} / \mathrm{z}(\%)$ $254\left(\mathrm{M}^{+}, 13.7\right), 198$ (100), 181 (32.9), 152 (41), 76 (17.1), 57 (41.3).

trans-tert-Butyl 3-(3-pyridyl)prop-2-enoate 45. Colorless crystals, mp. $56-57{ }^{\circ} \mathrm{C}$ (Ref. ${ }^{32} \mathrm{mp}$. $\left.57-58{ }^{\circ} \mathrm{C}\right) ;{ }^{1} \mathrm{H}$ NMR $\left(\mathrm{CDCl}_{3}\right) \delta 1.54\left(\mathrm{~s}, 9 \mathrm{H}, \mathrm{C}\left(\mathrm{CH}_{3}\right)_{4}\right), 6.43(\mathrm{~d}, 1 \mathrm{H}, J=15.9 \mathrm{~Hz}), 7.26-7.32(\mathrm{~m}$, $1 \mathrm{H}), 7.56(\mathrm{~d}, 1 \mathrm{H}, J=15.9 \mathrm{~Hz}), 7.79-7.82(\mathrm{~m}, 1 \mathrm{H}), 8.58(\mathrm{~d}, 1 \mathrm{H}, J=4.2 \mathrm{~Hz}), 8.72(\mathrm{~d}, 1 \mathrm{H}, J=1.8$ $\mathrm{Hz}$ ); MS m/z (\%) $205\left(\mathrm{M}^{+}, 4.6\right), 199$ (10.2), 182 (13), 150 (36.1), 132 (17.6), 120 (18.5), 104 (32.4), 93 (13), 77 (13), 57 (100). 
trans-tert-Butyl 3-(3-quinolyl)prop-2-enoate 46. Light yellow crystals, mp. 131-132 ${ }^{\circ} \mathrm{C}$ (Ref. $^{32}$ mp. 131-132 $\left.{ }^{\circ} \mathrm{C}\right) ;{ }^{1} \mathrm{H} \mathrm{NMR}\left(\mathrm{CDCl}_{3}\right) \delta 1.57\left(\mathrm{~s}, 9 \mathrm{H}, \mathrm{C}\left(\mathrm{CH}_{3}\right)_{4}\right), 6.61(\mathrm{~d}, 1 \mathrm{H}, J=16.2 \mathrm{~Hz}), 7.56-$ $7.71(\mathrm{~m}, 2 \mathrm{H}), 7.75(\mathrm{~d}, 1 \mathrm{H}, J=15.9 \mathrm{~Hz}), 7.86(\mathrm{~d}, 1 \mathrm{H}, J=7.8 \mathrm{~Hz}), 8.16(\mathrm{~d}, 1 \mathrm{H}, J=8.1 \mathrm{~Hz}), 8.27$ $(\mathrm{s}, 1 \mathrm{H}), 9.09(\mathrm{~s}, 1 \mathrm{H}) ;{ }^{13} \mathrm{C} \mathrm{NMR}\left(\mathrm{CDCl}_{3}\right) \delta 28.2,81.0,122.5,127.5,127.7,128.2,128.9,130.7$, 135.7, 139.7, 147.7, 148.7, 165.5; MS m/z (\%) $255\left(\mathrm{M}^{+}, 17.4\right), 199$ (92.8), 182 (45.8), 170 (25.6), 153 (20.8), 127 (24), 101 (8.8), 77 (26), 63 (13.2), 57 (100).

\section{References}

1. (a) Alonso, F.; Beletskaya, I. P.; Yus, M. Tetrahedron 2008, 64, 3047. (b) Bellina, F.; Carpita, A.; Rossi, R. Synthesis 2004, 15, 2419. (c) N. Miyaura, J. Organomet. Chem. 2002, 653, 54; (d) A. Suzuki, J. Organomet. Chem. 2002, 653, 83. (e) N. Miyaura and A. Suzuki, Chem. Rev. 1995, 95, 2457.

2. (a) Dai, M.; Liang, B.; Wang, C.; Chen, J.; Yang, Z. Org. Lett. 2004, 6, 221. (b) Yang, D.; Chen, Y. C.; Zhu, N. Y. Org. Lett. 2004, 6, 1577. (c) Li, J. H.; Liu, W. J. Org. Lett. 2004, 6, 2809. (d) Colacot, T. J.; Shea, H. A. Org. Lett. 2004, 6, 3731.

3. (a) Old, D. W.; Wolfe, J. P.; Buchwald, S. L. J. Am. Chem. Soc. 1998, 120, 9722. (b) Wolfe, J. P.; Singer, R. A.; Yang, B. H.; Buchwald, S. L. J. Am. Chem. Soc. 1999, 121, 9550. (c) Littke, A. F.; Dai, C.; Fu, G. C. J. Am. Chem. Soc. 2000, 122, 4020. (d) Mori, K.; Yamaguchi, K.; Hara, T.; Mizugaki, T.; Ebitani, K.; Kaneda, K. J. Am. Chem. Soc. 2002, 124, 11572. (e) Yin, J.; Rainka, M. P.; Zhang, X. X.; Buchwald, S. L. J. Am. Chem. Soc. 2002, 124, 1162.

4. (a) Bedford, R. B.; Cazin, C. S. J.; Hazelwood, S. L. Angew. Chem., Int. Ed. 2002, 41, 4120.

(b) Littke, A. F.; Fu, G. C. Angew. Chem., Int. Ed. 2002, 41, 4176. (c) Zhang, W.; Shi, M. Tetrahedron Lett. 2004, 45, 8921.

5. (a) Heck, R. F. Acc. Chem. Res. 1979, 12, 146. (b) Crisp, G. T. Chem. Soc. Rev. 1998, 27, 427. (c) Beletskaya, J. P.; Cheprakov, A. V. Chem. Rev. 2000, 100, 3009. (d) Dounay, A. B.; Overman, L. E. Chem. Rev. 2003, 103, 2945.

6. (a) Alonso, F.; Beletskaya, I. P.; Pages, M. Y. Tetrahedron 2005, 61, 11771. (c) Knowles, J. P.; Whiting A. Org. Biomol. Chem. 2007, 5, 31.

7. (a) Farina, V. Adv. Synth. Catal. 2004, 346, 1553. (b) Dupont, J.; Consorti, C. S.; Spencer, J. Chem. Rev. 2005, 105, 2527.

8. Dawood, K. M.; Kirschning, A. Tetrahedron 2005, 61, 12121.

9. Dawood, K. M. Tetrahedron 2007, 63, 9642.

10. Dawood, K. M.; Solodenko, W.; Kirschning, A. Arkivoc 2007, (v), 104.

11. (a) Ozdemir, I.; Cetinkaya, B.; Demir, S. J. Mol. Cat. A: Chem. 2004, 208, 109. (b) Demir, S.; Ozdemir, I.; Cetinkaya, B. Cetinkaya Appl. Organometal. Chem. 2006, 20, 254. 
12. (a) Pal, S.; Hwang, W.-S.; Lin, I. J. B.; Lee, C.-S. J. Mol. Cat. A: Chem. 2007, 269, 197. (b) Han, Y.; Huynh, H. V.; Koh L. L. J. Organomet. Chem. 2007, 692, 3606. (c) Hahn, F. E.; Jahnke, M. C.; Pape T. Organometallics 2007, 26, 150.

13. (a) Ozegowski, W.; Kerbs, D. J. Prak. Chem. 1965, iv, 301. (b) Bushey, D. F.; Johnson, B. F.; Huang, J. J. Org. Chem. 1985, 50, 2091.

14. Dupont, J.; Pfeffer, M.; Spencer, J. Eur. J. Inorg. Chem. 2001, 1917.

15. Herrmann, W. A.; Bohm, V. P. W.; Reisinger, C.-P. J. Organomet. Chem. 1999, 576, 23.

16. Phillips, M. A. J. Chem. Soc. 1928, 2393.

17. Molander, G. A.; Petrillo, D. E.; Landzberg, N. R.; Rohanna, J. C.; Biolatto, B. Synlett 2005, 1763.

18. Zahang, G. J. Chem. Res. 2004, 593.

19. (a) Nunez, A.; Sanchez, A.; Burgos, C.; Builla, J. A., Tetrahedron 2004, 60, 6217. (b) Sakamoto, T.; Kondo, Y.; Murata, N.; Yamanaka, H., Tetrahedron 1993, 49, 9713.

20. (a) Rudler, H.; Reville, T. D. J. Organomet. Chem. 2001, 617-618, 571; (b) Ishikura, M.; Oda, I.; Terashima, M., Heterocycles 1985, 23, 2375.

21. Mennecke, K.; Kirschning, A. Beilstein J. Org. Chem. 2009, 5, 21.

22. Wang, L. Org. Lett. 2009, 11, 1079.

23. Su, S.-J.; Tanaka, D.; Li, Y.-J.; Sasabe, H.; Takeda, T.; Kido, J. Org. Lett. 2008, 10, 941.

24. Ishikura, M.; Oda, I.; Terashima, M. Heterocycles 1985, 23, 2375.

25. Denmark, S. E.; Wang, Z. Org. Lett. 2001, 3, 1073.

26. (a) Mao, J.; Guo, J.; Fang, F.; Ji, S.-J. Tetrahedron 2008, 64 3905; (b) Beaven, G. H.; De LaMare, P. B. D.; Hassan, M.; Johnson, E. A.; Klassen, N. V. J. Chem. Soc. 1961, 2749.

27. Brito, C. M.; Pinto, D. C. G. A.; Silva, A. M. S.; Silva, A. M. G.; Tome, A. C.; Cavaleiro, J. A. S. Eur. J. Org. Chem. 2006, 2558.

28. Shi, S.; Zhang, Y. Green Chem. 2008, 10, 868.

29. Doi, H.; Sakai, T.; Iguchi, M.; Yamada, K.-I.; Tomioka, K. J. Am. Chem. Soc. 2003, 125, 2886.

30. Bezou, P.; Hilberer, A.; Hadziioannou, G. Synthesis 1996, 449.

31. Li, S.-W.; Zhou, Z.-L.; Huang, Y.-Z.; Shi L.-L. J. Chem. Soc. Perkin Trans. 1 1991, 1099.

32. Al-Hashimi, M.; Sullivan, A. C.; Wilson, J. R. H. J. Mol. Cat. A: Chem. 2007, 273, 298. 